\title{
ANALISIS KARAKTERISTIK BODI DAN CHASSIS PADA PROTOTYPE KENDARAAN LISTRIK
}

\author{
Arya Yudistira Dwinanto, Fadhil Burhanuddin Muhammad \\ Jurusan Teknik Mesin, Fakultas Teknik, Universitas Brawijaya ; Jl. Mayjend. Haryono No. 167, \\ Malang,65145, Indonesia \\ Telp. : +62-341-552941; Fax : +62-341-551430 \\ aryatekmesin@gmail.com
}

\begin{abstract}
In the design of electric vehicles prototype, there are many things that must be taken into account and considered to be used completely without danger and failure in materials. In general, they are the design of body, chassis or frame design, the design of the transmission system, the design of the engine (motor), and the design of electrical installations. Vehicle chassis monocoque has a lighter weight compared to the vehicle chassis with a ladder. The weight of the vehicle has a considerable effect on the efficiency of the motor in which the motor work harder. Body vehicle glass fiber and carbon fiber also has a weight that is much different. With the same frame, the vehicle weight is obtained with a machine that utilizes carbon fiber body and fiber glass $43 \mathrm{kgf}$ and $54 \mathrm{kgf}$. Excess carbon fiber monocoque chassis can be combined to produce the weight of the vehicle $36 \mathrm{kgf}$.
\end{abstract}

Keywords: Carbon Fiber ; Monocoque ; Ladder ; Frame ; Fiber Glass ; Weight ; Efficiency

\section{PENDAHULUAN}

Kendaraan listrik merupakan salah satu alternatif untuk mengatasi permasalahan krisis energi dan lingkungan. Hal ini dikarenakan kendaraan listrik tidak membutuhkan bahan bakar fosil dan tidak menghasilkan polusi seperti halnya kendaraan bermotor. namun terdapat beberapa kemiripan komponen antara kendaraan listrik dengan kendaraan bermotor, antara lain adalah bodi dan chassis kendaraan.

Karakteristik bodi dapat dipengaruhi material pembentuk bodi walaupun geometri memiliki pengaruh yang tidak begitu besar. Terdapat berbagai macam material pembentuk bodi dan chassis. Pada manufaktur bodi kendaraan dan chassis, material yang digunakan dapat berupa logam dan komposit. Logam sebagai material pada bodi kendaraan dapat kita temui pada kendaraan disekitar kita. Namun, biasanya juga terdapat kendaraan yang memakai material komposit . Komposit memiliki kelebihan dibandingkan dengan logam, yaitu dalam hal massa jenis yang lebih kecil, serta nilai kekerasan yang lebih besar [4]. Massa jenis menentukan bobot bodi sedangkan kekerasan berpengaruh pada kekakuan. Komposit yang menjadi material pada manufaktur bodi diantaranya adalah fiber glass dan carbon fiber.

Karakteristik chassis dapat dipengaruhi oleh material dan struktur chassis. Terdapat berbagai struktur chassis, diantaranya adalah monocoque chassis dan ladder structure. Material chassis dapat berupa logam ataupun komposit. Material komposit pada chassis tidak seperti komposit pada bodi kendaraan yang reinforcement-nya berupa fiber, komposit pada chassis lebih pada struktur sebagai reinforcement-nya, seperti foam core structure dengan struktur chassis berupa monocoque structure. Sedangkan material chassis yang berupa logam, biasanya logam yang digunakan dapat berupa allumunium paduan dengan struktur chassis yang dapat berupa ladder structure.

Untuk itu perlu dilakukan kajian bodi dan chassis pada kendaraan listrik dengan subjek berupa prototype kendaraan listrik dengan harapan dapat mengetahui kelebihan serta kekurangan pada bodi dan chassis dari prototype-prototype yang dikaji sehingga dapat dijadikan bahan rujukan dalam perencanaan kendaraan listrik. 


\section{METODOLOGI PENELITIAN}

\section{A. Metode Pengambilan Data}

Dalam penelitian ini digunakan dua metode dalam pengumpulan data. Adapun metode penelitian yang digunakan ini adalah sebagai berikut :

1. Metode Penelitian Kepustakaan (Library Research)

Metode ini digunakan dalam mendapatkan data dengan caraobservasi dengan literatur yang digunakan. Kemudian juga dengan membaca sumber-sumber data informasi lainnya yang berhubungan dengan pembahasan. Sehingga dengan penelitian kepustakaan ini diperoleh secara teori mengenai permasalahan yang dibahas.

2. Metode Penelitian Lapangan (Field Research)

Metode ini digunakan dalam pengumpulan data, dimana penyelidik secara langsung terjun pada proyek penelitian, sedangkan cara lain yang dipakai dalam Field Research ini adalah :

a. Interview, metode ini digunakan dalam mendapatkan data dengan jalan mengajukan pertanyaan secara langsung kepada tim kendaraan listrik yang ikut berpartisipasi.

b. Observasi, yaitu suatu metode dalam memperoleh data, dengan mengadakan pengamatan langsung terhadap keadaan yang sebenarnya dalam penelitian.

c. Dokumentasi, yaitu mengumpulkan data menurut metode ini penulis mencatat dari data dokumen yang ada kaitannya dengan kendaraan listrik yang menjadi objek penelitian.

B. Kerangka Pemikiran

1. Komposit

Menurut Matthews dkk. (1993), komposit adalah suatu material yang terbentuk dari kombinasi dua atau lebih material pembentuknya melalui campuran yang tidak homogen, dimana sifat mekanik dari masing-masingmaterial pembentuknya berbeda [1]. Dari campuran tersebut akan dihasilkan material komposit yang mempunyai sifat mekanik dan karakteristik ini yang berbeda dari material pembentuknya. Material komposit mempunyai sifat dari material konvensional pada umumnya dari proses pembuatannya melalui percampuran yang tidak homogen, sehingga kita leluasa merencanakan kekuatan material komposit yang kita inginkan dengan jalan mengatur komposisi dari material pembentuknya. Komposit merupakan sejumlah sistem multi fasa sifat dengan gabungan, yaitu gabungan antara bahan matriks atau pengikat dengan penguat.

Kroschwitz dan rekan telah menyatakan bahwa komposit adalah bahan yang terbentuk apabila dua atau lebih komponen yang berlainan digabungkan. Rosato dan di Matitia pula menyatakan bahwa plastik dan bahan-bahan penguat yang biasanya dalam bentuk serat, dimana ada serat pendek, panjang, anyaman pabrik atau lainnya [2].

2. Fiber sebagai penguat (Fiber composites)

Fungsi utama dari serat adalah sebagai penopang kekuatan dari komposit, sehingga tinggi rendahnya kekuatan komposit sangat tergantung dari serat yang digunakan, karena tegangan yang dikenakan pada komposit mulanya diterima oleh matrik akan diteruskan kepada serat, sehingga serat akan menahan beban sampai beban maksimum. Oleh karena itu serat harus mempunyai tegangan tarik dan modulus elastisitas yang lebih tinggi daripada matrik penyusun komposit.

3. Hybrid fiber composite

Hybrid fiber composite merupakan komposit gabungan antara tipe serat lurus dengan serat acak. Pertimbangannya supaya dapat mengeliminir kekurangan sifat dari kedua tipe dan dapat menggabungkan kelebihannya. Jenis fiber yang biasa digunakan untuk pembuatan komposit antara lain sebagai berikut :

a) Fiber-glass

Sifat-sifat fiber-glass, yaitu sebagai berikut :

1. Density cukup rendah (sekitar 2,55 $\mathrm{g} / \mathrm{cc}$ )

2. Tensile strengthnya cukup tinggi (sekitar 1,8 GPa)

3. Biasanya stiffnessnya rendah (70GPa)

4. Stabilitas dimensinya baik

5. Resisten terhadap panas dan dengin 
6. Tahan korosi

7. Komposisi umum adalah $50-60 \%$ $\mathrm{SiO}_{2}$ dan paduan lain yaitu $\mathrm{Al}$,

$\mathrm{Ca}, \mathrm{Mg}, \mathrm{Na}$, dan lain-lain.

Keuntungan dari penggunaan fiberglass yaitu sebagai berikut :

1. Biaya murah

2. Tahan korosi

3. Biayanya relatif lebih rendah dari komposit lainnya

4. Biasanya digunakan untuk piing, tanks, boats, alat-alat olahraga Kerugian dari penggunaan fiberglass yaitu sebagai berikut :

1. Kekuatannya relatif rendah

2. Elongasi tinggi

3. Kekuatan dan beratnya sedang (moderate)

b) Fiber-carbon

Sifat-sifat fiber-carbon, yaitu sebagai berikut :

1. Densitas karbon cukup ringan yaitu sekitar 2,3 g/cc.

2. Struktur grafit yang digunakan untuk membuat fiber berbentuk seperti kristal intan.

3. Mempunyai karakteristik yang ringan, kekuatan yang sangat tinggi, kekakuan (modulus elastisitas) tinggi.

4. Memisahkan bagian yang bukan karbon melalui proses

5. Terdiri dari $\pm 90 \%$ karbon

6. Dapat dibuat bahan turunan : grafit yang kekuatannya dibawah serat karbon

7. Diproduksi dari Polyacrylnitril (PAN), melalui tiga tahap proses, yaitu sebagai berikut :

- Stabilisasi = Peregangan dan oksidasi.

- Karbonisasi = Pemanasan untuk mengurangi $\mathrm{O}, \mathrm{H}, \mathrm{N}$

Grafitisasi $=$ Meningkatkan modulus elastisitas.

4. Fiber sebagai struktural (Structure composites)

Komposit struktural dibentuk oleh reinforce- reinforce yang memiliki bentuk lembaran-lembaran. Berdasarkan struktur, komposit dapat dibagi menjadi dua yaitu struktur laminate dan struktur sandwich, ilustrasi dari kedua struktur komposit tersebut dapat dilihat pada Gambar 8.

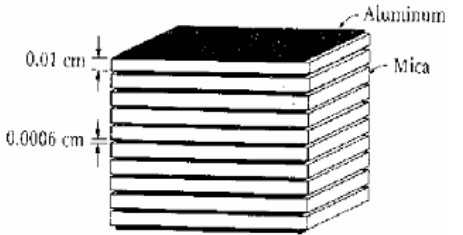

a

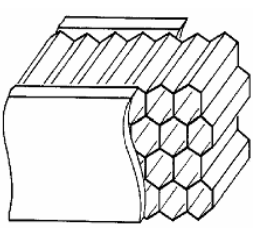

b
Gambar 1. Ilustrasi komposit berdasarkan

Strukturnya : a. Struktur laminate b. Sandwich panel

\section{Foam Core Structure}

6. Chassis Structure

a. Ladder Chassis

Keuntungan dari chassis ladder adalah sebagai berikut:

- Mudah untuk didesain, dibangun, dan dimodifikasi

- Lebih cocok untuk kendaraan berat yang suka off-road dan lebih tahan lama

- Mudah untuk di reparasi bila terjadi tumbukan

Kelemahan dari chassis ladder adalah sebagai berikut:

- Lebih berat dibandingkan chassis model lainnya

- Performance-nya lebih rendah dibandingkan chassis model lain

- Efisiensi lebih rendah

- Torsi rendah saat melewati tikungan

- Mudah terguling

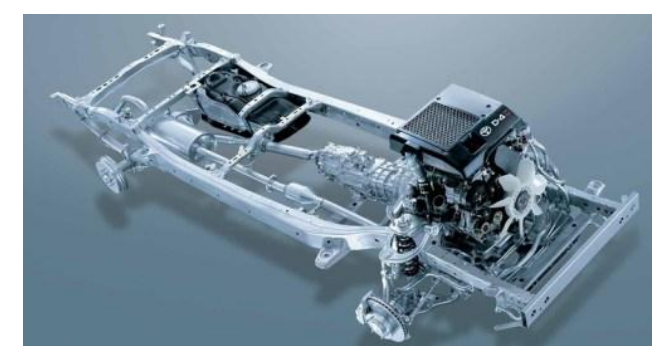

Gambar 2. Mobil dengan chassis ladder

b. Tipe Rangka Monocoque

Chassis ini merupakan satu kesatuan dengan body. Rangka tipe ini sudah tidak menggnakan chassis batang lagi, melainkan menggabungkan setiap komponen body mobil sehingga dapat menopang mesin, kopling, transmisi, diferensial, dll. 
Keuntungan dari rangka ini adalah:

- Bobot paling ringan

- Handling lebih lembut

- Ground clearance lebih rendah

Kekurangan dari rangka ini adalah:

- Sangat sulit diperbaiki

- Sulit untuk dilakukan perombakan

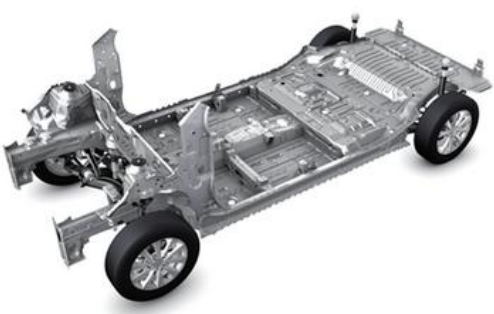

Gambar 3. Mobil dengan chassis monocoque

C. Tabel-tabel

Tabel 1. Tabel Perbandingan Properti Komposit

\begin{tabular}{|c|c|c|c|c|c|c|}
\hline \multicolumn{2}{|c|}{ Material } & $\mathrm{lbs} / \mathrm{ft}^{3}$ & $\mathrm{gm} / \mathrm{cm}^{3}$ & psi $\times 10^{6}$ & Gpa & $\%$ \\
\hline \multirow{2}{*}{ Fibers } & Eglass (24 or WR) & 162,4 & 2,6 & 10,5 & 72,45 & 4,8 \\
\cline { 2 - 7 } & Carbon-PAN & 109,7 & 1,76 & $33-57$ & $227-393$ & $0,38-2$ \\
\hline \multirow{2}{*}{ Laminates } & Polyester hand lay up & 96 & 1,54 & 1,4 & 9,66 & $\mathrm{n} / \mathrm{a}$ \\
\cline { 2 - 7 } & Carbon Epoxy & 97 & 1,55 & 8,7 & 60 & $\mathrm{n} / \mathrm{a}$ \\
\hline Metals & Alumunium 6061 & 169,3 & 2,71 & 10 & 69 & 10 \\
\hline
\end{tabular}

Tabel 2. Kelebihan Versus Kekurangan

\begin{tabular}{|c|c|c|}
\hline Fiber & Kelebihan & Kekurangan \\
\hline $\begin{array}{l}\text { Fiber- } \\
\text { glass }\end{array}$ & $\begin{array}{l}\text { 1. Kekuatan } \\
\text { tinggi } \\
\text { 2. Relatif murah }\end{array}$ & $\begin{array}{l}\text { Kurang } \\
\text { elastis }\end{array}$ \\
\hline $\begin{array}{l}\text { Fiber- } \\
\text { carbon }\end{array}$ & $\begin{array}{l}\text { 1. Lebih kuat } \\
\text { dibandingkan } \\
\text { fiber-glass } \\
\text { 2. Stiffness(kuat+ } \\
\text { keras) besar } \\
\text { 3. Koefisien } \\
\text { pemuaian kecil } \\
\text { 4. Menahan } \\
\text { getaran }\end{array}$ & $\begin{array}{l}\text { 1. Agak } \\
\text { getas } \\
\text { 2. Nilai } \\
\text { peregang } \\
\text { an kurang } \\
\text { 3. Agak } \\
\text { mahal }\end{array}$ \\
\hline
\end{tabular}

D. Flowchart Penelitian

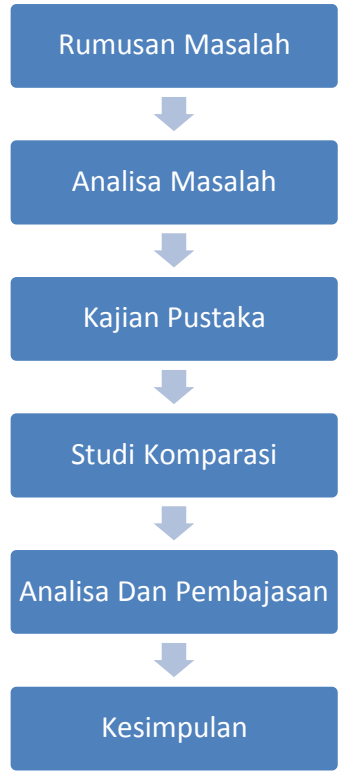

E. Spesifikasi Subjek Penelitian 1. Aristo EV 3

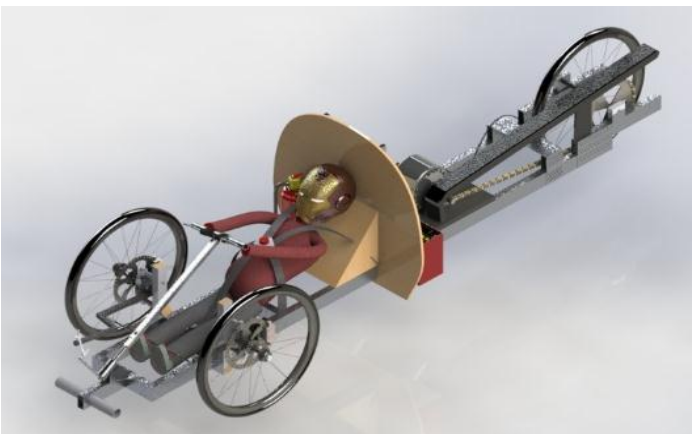

Gambar 4. Aristo EV-3 tampak isometri

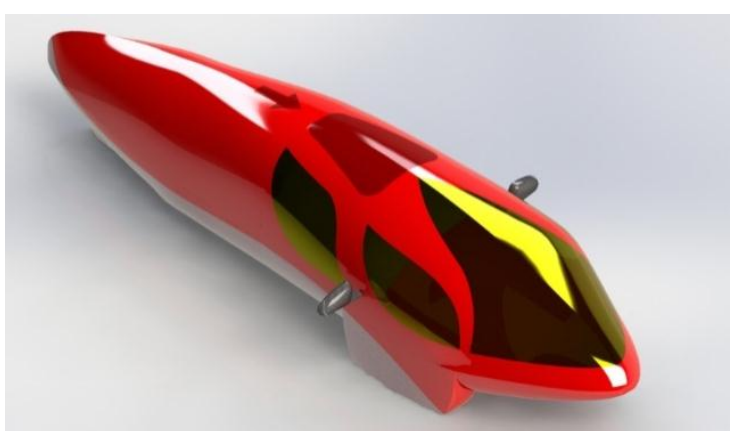

Gambar 5. Body Aristo Evo 3 tampak isometri 


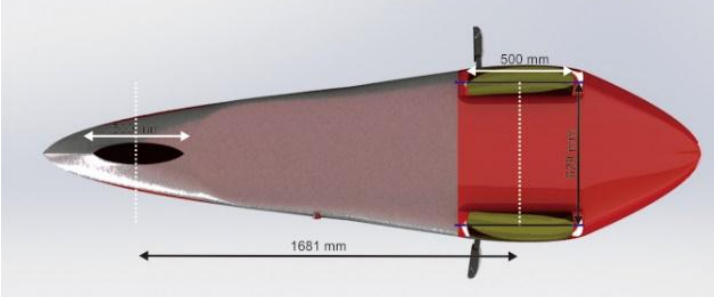

Gambar 6. Track width, wheelbase dan diameter roda

a. Dimensi

- Track width $=629 \mathrm{~mm}$

- Compartment Engine $=254,8 \mathrm{~mm} x$ $287 \mathrm{~mm}$

- Wheel Base $=1681 \mathrm{~mm}$

- Roll Bar $=290583.5 \mathrm{~mm}^{2}$

- Body Length = $3000 \mathrm{~mm}$

- Body Height = 689,5 mm

b. Vehicle Detail

- Vehicle name : Aristo Evo III

- Vehicle type : Prototype Diesel

- Built by : Apatte - 62 Universitas Brawijaya

- Body : Glass Fiber Reinforcement Plastic

- Chassis

Alumunium Ladder

- Dimension $300 \mathrm{~cm} \mathrm{x}$ $81,5 \mathrm{~cm} \mathrm{68,95} \mathrm{cm}$

- Power Source : Battery LiFePO4 cells

- Weight : $54 \mathrm{~kg}$

- Transmission Rasio : Single transmission

\section{Aristo EV 1}

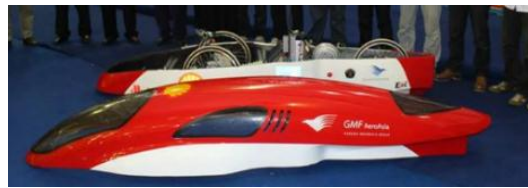

Gambar 7. Aristo EV-1

a. Dimensi

- Track width $=641 \mathrm{~mm}$

- Compartment Engine = 250,4 mm x $277 \mathrm{~mm}$

- Wheel Base = $1711 \mathrm{~mm}$

- Roll Bar = $295144.2 \mathrm{~mm}^{2}$
- Body Length = $3100 \mathrm{~mm}$

- Body Height = 690,6 mm

b. Vehicle Detail

- Vehicle name : Aristo

Evo - I

- Vehicle type : Prototype

Listrik

- Built by : Apatte - 62

Universitas Brawijaya

- Body

: CarbonFiber

Reinforcement Plastic

- Chassis

: Alumunium

Ladder

- Dimension

: $310 \mathrm{~cm} \mathrm{x}$

$81,5 \mathrm{~cm} \mathrm{69,06} \mathrm{cm}$

- Power Source

LiFePO4 cells

- Weight

Battery

- Transmission Rasio transmission

3. Keris R-VII

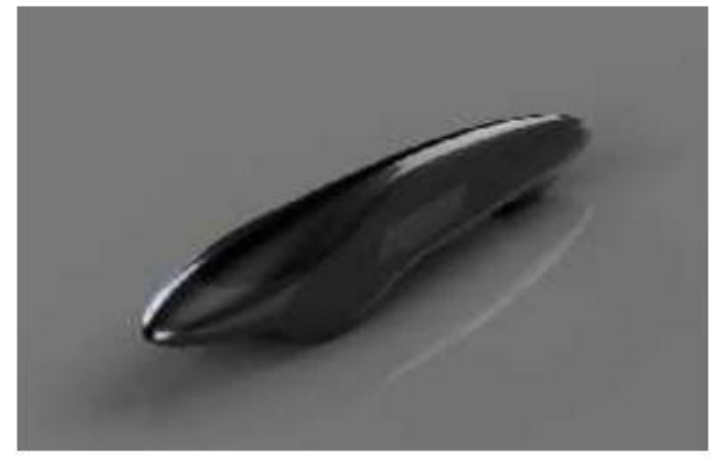

Gambar 8. Bodi Keris R-VII Tampak Isometri

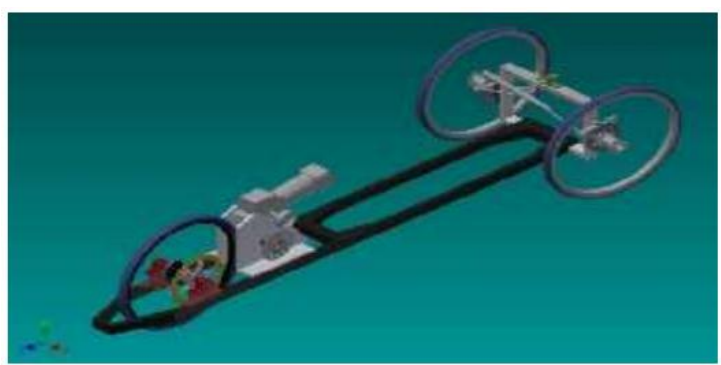

Gambar 9. Chassis Keris R-VII Tampak Isometri

a. Dimensi

- Track width $=560 \mathrm{~mm}$

- Compartment Engine $=230 \mathrm{~mm} \mathrm{x}$ $252 \mathrm{~mm}$ 
- Wheel Base $=1320 \mathrm{~mm}$

- Roll Bar = $237751.8 \mathrm{~mm}^{2}$

- Body Length $=2800 \mathrm{~mm}$

- Body Height $=550 \mathrm{~mm}$

b. Vehicle Detail

- Vehicle name : Keris R-VII

- Vehicle type : Prototype Listrik

- Built by : Nakoela Hore

Universitas Indonesia

- Body

- Chassis

(Foam Core)

- Dimension

$81,5 \mathrm{~cm} \times 55 \mathrm{~cm}$

- Power Source

LiFePO4 cells

- Weight

: Carbon Fiber

- Transmission Rasio transmission

\section{HASIL DAN PEMBAHASAN}

Pada tabel - tabel di bawah, terdapat parameter-parameter yang akan dibandingkan, antara lain material serta struktur bodi dan sasis, berat prototype, serta pencapaian jarak tempuh per kWh.

Dari ketiga parameter tersebut, yang akan dijadikan acuan adalah pencapaian jarak tempuh per $\mathrm{kWh}$, sedangkan material serta struktur bodi dan sasis dijadikan dasaran yang nantinya memiliki hubungan sebab akibat dengan pencapaian jarak tempuh per kWh.

Tabel 4. Perbandingan Prototype

\begin{tabular}{|c|c|l|c|c|}
\hline $\begin{array}{c}\text { Nama } \\
\text { Prototype }\end{array}$ & Dimensi & Bodi dan sasis & $\begin{array}{c}\text { Berat } \\
\text { (kg) }\end{array}$ & $\begin{array}{c}\text { Pencapaian } \\
\text { (kWh) }\end{array}$ \\
\hline Aristo Ev-3 & $\begin{array}{l}300 \mathrm{~cm} \times 81,5 \\
\mathrm{~cm} \times 68,95 \mathrm{~cm}\end{array}$ & $\begin{array}{l}\text { Bodi : Glass } \\
\text { Fiber } \\
\text { Reinforcement } \\
\text { Plastic } \\
\text { Chassis : } \\
\text { Alumunium } \\
\text { Ladder }\end{array}$ & 54 & 274 \\
\hline Aristo Ev-1 & $\begin{array}{l}310 \mathrm{~cm} \times 81,5 \\
\mathrm{~cm} 69,06 \mathrm{~cm}\end{array}$ & $\begin{array}{l}\text { Redi : Carbon } \\
\text { Riber } \\
\text { Plastic } \\
\text { Chassis : } \\
\text { Alumunium } \\
\text { Ladder }\end{array}$ & 43 & 324 \\
\hline Keris R-VII & $\begin{array}{c}280 \mathrm{~cm} \times 81,5 \\
\mathrm{~cm} \times 55 \mathrm{~cm}\end{array}$ & $\begin{array}{l}\text { Body : Carbon } \\
\text { Fiber } \\
\text { Chassis : Foam } \\
\text { Core }\end{array}$ & 42 & 345 \\
\hline
\end{tabular}

Material pembentuk bodi dari ketiga prototype berupa carbon fiber dan glass fiber. Prototype yang memakai glass fiber pada prototypenya adalah Aristo Ev-3 sedangkan prototype Aristo Ev-1 dan Keris R-VII menggunakan carbon fiber sebagai material pembentuk bodi.

Tabel 5. Kelebihan dan Kekurangan Struktur Chassis

\begin{tabular}{|c|c|c|}
\hline $\begin{array}{l}\text { Jenis } \\
\text { Struktur }\end{array}$ & Kelebihan & Kekurangan \\
\hline \multirow{5}{*}{$\begin{array}{l}\text { Ladder } \\
\text { Structure }\end{array}$} & $\begin{array}{l}\text { Mudah untuk } \\
\text { didesain, } \\
\text { dibangun, dan } \\
\text { dimodifikasi }\end{array}$ & $\begin{array}{l}\text { Lebih berat } \\
\text { dibandingkan } \\
\text { chassis } \\
\text { model lainnya }\end{array}$ \\
\hline & \multirow{2}{*}{$\begin{array}{l}\text { Lebih cocok } \\
\text { untuk } \\
\text { kendaraan } \\
\text { berat yang } \\
\text { suka off-road } \\
\text { dan lebih } \\
\text { tahan lama }\end{array}$} & $\begin{array}{l}\text { Performance- } \\
\text { nya lebih } \\
\text { rendah } \\
\text { dibandingkan } \\
\text { chassis } \\
\text { model lain }\end{array}$ \\
\hline & & $\begin{array}{l}\text { Efisiensi lebih } \\
\text { rendah }\end{array}$ \\
\hline & \multirow{2}{*}{$\begin{array}{l}\text { Mudah untuk } \\
\text { di reparasi } \\
\text { bila terjadi } \\
\text { tumbukan }\end{array}$} & $\begin{array}{l}\text { Torsi rendah } \\
\text { saat melewati } \\
\text { tikungan }\end{array}$ \\
\hline & & $\begin{array}{l}\text { Mudah } \\
\text { terguling }\end{array}$ \\
\hline \multirow{3}{*}{$\begin{array}{l}\text { Monocoque } \\
\text { Structure }\end{array}$} & $\begin{array}{l}\text { Bobot paling } \\
\text { ringan }\end{array}$ & $\begin{array}{l}\text { Sangat sulit } \\
\text { diperbaiki }\end{array}$ \\
\hline & $\begin{array}{l}\text { Handling } \\
\text { lebih lembut }\end{array}$ & \multirow{2}{*}{$\begin{array}{l}\text { Sulit untuk } \\
\text { dilakukan } \\
\text { perombakan }\end{array}$} \\
\hline & $\begin{array}{l}\text { Ground } \\
\text { clearance } \\
\text { lebih rendah }\end{array}$ & \\
\hline
\end{tabular}

1. Analisa chassis prototype

Pada bagian sasis, prototype Aristo Ev-1 dan Aristo Ev-3 menggunakan Ladder Chassis dengan material Alumunium sedangkan Keris R-VII menggunakan struktur sasis monocoque dengan menggunakan material foam core.

Berdasarkan dasar teori, maka Aristo Ev1 dan Aristo Ev-3 memiliki sifat bobot paling berat diantara jenis struktur sasis lain (hal ini sesuai dengan data pada tabel 4.) performance-nya lebih rendah dibandingkan 
chassis model lain, efisiensi lebih rendah, torsi tarik 2415-4830 Mpa, dan elongasi maksimal rendah saat melewati tikungan, mudah 0.38-2.0\%.

terguling sedangkan Keris R-VII memiliki sifat bobot paling ringan (hal ini sesuai dengan data pada tebel 4), handling lebih lembut, ground clearance lebih rendah (hal ini sesuai dengan data pada tebel 4), sangat sulit diperbaiki, sulit untuk dilakukan perombakan.

Tabel 6. Kelebihan dan Kekurangan Material Bodi

\begin{tabular}{|c|c|c|}
\hline \multirow{2}{*}{ Kelebihan } & \multicolumn{2}{|c|}{ Jenis Material Bodi } \\
\cline { 2 - 3 } & $\begin{array}{c}\text { Fiber } \\
\text { Glass }\end{array}$ & $\begin{array}{c}\text { Carbon } \\
\text { Fiber }\end{array}$ \\
\hline Biaya murah & $\mathbf{v}$ & - \\
\hline Tahan korosi & $\mathbf{v}$ & $\mathbf{v}$ \\
\hline $\begin{array}{c}\text { Biayanya relatif } \\
\text { lebih rendah dari } \\
\text { komposit lainnya }\end{array}$ & $\mathbf{v}$ & - \\
\hline $\begin{array}{c}\text { Mempunyai } \\
\text { karakteristik yang } \\
\text { ringan, kekuatan } \\
\text { yang sangat } \\
\text { tinggi, kekakuan } \\
\text { (modulus } \\
\text { elastisitas) tinggi. }\end{array}$ & $\mathbf{v}$ & $\mathbf{v} \mathbf{v} \mathbf{}$ \\
\hline $\begin{array}{c}\text { Dapat dibuat } \\
\text { bahan turunan : } \\
\text { grafit yang } \\
\text { kekuatannya } \\
\text { dibawah serat } \\
\text { karbon }\end{array}$ & - & $\mathbf{v}$ \\
\hline Densitas & $\mathbf{v}$ & $\mathbf{v} \mathbf{v} \mathbf{~}$ \\
\hline
\end{tabular}

Skala Penilaian :

$$
\begin{aligned}
\mathbf{v}: & \text { Cukup } \\
\mathbf{v} \mathbf{v}: & \text { Baik } \\
\mathbf{v} \mathbf{v}: & \text { Sangat Baik }
\end{aligned}
$$

\section{Analisa material body prototype}

Berdasarkan Tabel. 3, kita dapat melihat nilai properti tiap komposit. Glass fiber (S class), memiliki nilai massa jenis $2,49 \mathrm{gr} / \mathrm{cm}^{3}$, kekuatan tarik $4589 \mathrm{Mpa}$, dan elongasi maksimal 5,7 \% sedangkan carbon fiber memiliki massa jenis $1,76 \mathrm{gr} / \mathrm{cm}^{3}$, kekuatan
Carbon fiber memiliki nilai massa jenis yang lebih rendah dari glass fiber sehingga menjadikan carbon fiber memiliki berat yang lebih ringan dari glass fiber. Hal ini dapat dibuktikan dengan lebih ringannya berat prototype Aristo Ev-1 dan Keris R-VII dibandingkan dengan Aristo Ev-3. Bodi pada prototype Aristo Ev-1 dan Keris R-VII memiliki kekuatan tarik yang lebih besar dibandingkan dengan Aristo Ev-3 yang menggunakan glass fiber sebagai material pembentuk bodi. Nilai elongasi pada prototype Aristo Ev-1 dan Keris R-VII lebih rendah dari Aristo Ev-3 sehingga menjadikan prototype Aristo Ev-1 dan Keris RVII memiliki struktur bodi yang lebih kaku dan keras.

2. Analisa akhir

Berdasarkan analisa sebelumnya, dari ketiga prototype, prototype dengan beban terbesar adalah Aristo Ev-3, sedangkan yang paling ringan adalah Keris R-VII.

Berdasarkan tabel 4, nilai jarak tempuh pada masing masing prototype adalah Aristo Ev-1 324 km/kWh, Aristo Ev-3 274 km/kWh, sedangkan Keris R-VII 345 km/kWh.

Hal ini sesuai dengan dasar teori, dimana beban kendaraan mempengaruhi konsumsi listrik pada motor listrik dan komsumsi listrik akan mempengaruhi jarak tempuh. Semakin berat beban kendaraan, maka konsumsi daya listrik yang dibutuhkan akan semakin besar, begitu juga sebaliknya sehingga jika konsumsi daya listrik semakin besar, maka jarak tempuh yang didapat akan semakin pendek.

\section{KESIMPULAN}

1. Bodi dan sasis memiliki kontribusi penting dalam menentukan beban pada prototype.

2. Dari ketiga prototype, prototype dengan beban terbesar adalah Aristo Ev-3, kemudian Aristo Ev-1 dan yang paling ringan adalah Keris R-VII.

3. Prototype dengan beban terberat, memiliki nilai konsumsi bahan bakar terendah, begitu juga sebaliknya. 
DAFTAR PUSTAKA

[1] Matthews, F.L., Rawlings, RD., 1993, Composite Material Engineering And Science, Imperial College Of Science, Technology And Medi-cine, London, UK.

[2] M. M. Schwartz, 1984. Composite Materials Handbook. New York : McGraw-. Hill Inc.
[3] Courtney, TH., 1999, Mechanical Behavi-or Of Material, Mc Graw, Hill In-ternational Engineering, Material Science/Metallurgy Series.

[4] Van Vlack, LH., 1994, terjemahan Japrie, S. Ilmu dan Teknologi Bahan, E-disi kelima, Erlangga, Jakarta. 